\title{
Characterization of recombinant human lysosomal beta-hexosaminidases produced in the methylotrophic yeast Pichia pastoris
}

\author{
Angela J. Espejo-Mojica ${ }^{1}$, Angela Mosquera ${ }^{1}$, Alexander Rodríguez-López ${ }^{1,2}$, Dennis Díaz', \\ Laura Beltrán ${ }^{1}$, Francy Liliana Hernandez ${ }^{1}$, Carlos J. Alméciga-Díaz ${ }^{1, *}$, Luis A. Barrera ${ }^{1,3, * *}$
}

\author{
Edited by \\ Juan Carlos Salcedo-Reyes \\ (salcedo.juan@javeriana.edu.co) \\ 1. Institute for the Study of Inborn \\ Errors of Metabolism, School of \\ Sciences, Pontificia Universidad \\ Javeriana. Bogotá, Colombia \\ 2. Chemistry Department, School of \\ Science, Pontificia Universidad Javeriana, \\ Bogotá, Colombia \\ 3. Clínica de Errores Innatos del \\ Metabolismo. Hospital Universitario San \\ Ignacio. Bogotá, Colombia. \\ *cjalmeciga@javeriana.edu.co \\ ** abarrera@javeriana.edu.co \\ Received: 16-07-2016 \\ Accepted: 09-08-2016 \\ Published on line: 31-08-2016 \\ Citation: Espejo-Mojica AJ, Mosquera \\ A, Rodríguez-López A, Díaz D, \\ Beltrán L, Hernández FL, Alméciga- \\ Díaz CJ, Barrera LA. Characterization \\ of recombinant human lysosomal \\ beta-hexosaminidases produced in the \\ methylotrophic yeast Pichia pastoris, \\ Universitas Scientiarum, 21 (3): 195-217, 2016. \\ doi: 10.11144/Javeriana.SC21-3.corh \\ Funding: \\ Administrative Department of \\ Science, Technology and Innovation \\ COLCIENCIAS and Pontificia \\ Universidad Javeriana \\ Electronic supplementary material: \\ $\mathrm{N} / \mathrm{A}$ \\ OPEN ACCESS
}

\begin{abstract}
$\beta$-hexosaminidases (Hex) are dimeric enzymes involved in the lysosomal degradation of glycolipids and glycans. They are formed by $\alpha$ - and/or $\beta$-subunits encoded by HEXA and HEXB genes, respectively. Mutations in these genes lead to Tay Sachs or Sandhoff diseases, which are neurodegenerative disorders caused by the accumulation of non-degraded glycolipids. Although tissue-derived Hex have been widely characterized, limited information is available for recombinant $\beta$-hexosaminidases. In this study, human lysosomal recombinant Hex (rhHex-A, rhHex-B, and rhHex-S) were produced in the methylotrophic yeast Pichia pastoris GS115. The highest specific enzyme activities were 13,124 for rhHexA; 12,779 for rhHex-B; and 14,606 U . $\mathrm{mg}^{-1}$ for rhHex-S. These results were 25- to 50-fold higher than those obtained from normal human leukocytes. Proteins were purified and characterized at different $\mathrm{pH}$ and temperature conditions. All proteins were stable at acidic $\mathrm{pH}$, and at $4{ }^{\circ} \mathrm{C}$ and $37^{\circ} \mathrm{C}$. At $45^{\circ} \mathrm{C}$ rhHex-S was completely inactivated, while rhHex-A and rhHex-B showed high stability. This study demonstrates P. pastoris GS115 potential for polymeric lysosomal enzyme production, and describes the characterization of recombinant $\beta$-hexosaminidases produced within the same host.
\end{abstract}

Keywords: $\beta$ - $N$-acetylhexosaminidases; characterization; Pichia pastoris; recombinant hexosaminidases; Sandhoff disease; Tay Sachs disease.

\section{Introduction}

Tay Sachs (TSD, OMIM \#272800) and Sandhoff (SD, OMIM \#268800) diseases are lysosomal storage disorders (LSD) known as GM2 Gangliosidosis. They are autosomal recessive disorders caused by mutations in $H E X A$ or $H E X B$ genes, which encode for the $\alpha$ - or $\beta$-subunits, respectively, of the human lysosomal $\beta$ - $N$-acetylhexosaminidases (Hex, EC 3.2.1.52) A, B, or S [1,2]. TSD and SD are clinically indistinguishable, except that in SD central nervous system (CNS) and visceral organs are affected, whereas in TSD only the CNS is impaired. Clinically, these disorders are characterized by apathy, hyperacusis, motor weakness, hypotonia, poor head control, decreasing attentiveness, 
usual appearance of a macular cherry-red spot in the retina, seizures, and progressive mental deterioration followed by blindness, deafness, and spasticity, leading to a state of decerebrate rigidity. Patients usually die around 3 years of age [3].

Currently, specific therapy for TSD and SD is not available. Nevertheless, some experimental therapies include enzyme replacement therapy (ERT), bone marrow or neural progenitor cell transplantation, gene therapy, and substrate deprivation therapy [4]. Pre-clinical studies of ERT for GM2 gangliosidoses have been conducted using a recombinant modified Hex-B produced in Chinese Hamster Ovary ( $\mathrm{CHO}$ ) cells, which allowed in-vitro GM2 ganglioside storage reduction and in the parenchyma of intracerebroventricularly injected mice [5]. Furthermore, the use of a highly mannosylated recombinant Hex-A enzyme produced in Ogataea minuta yeast resulted in GM2 storage reduction and $7.8 \%$ lifespan increase in the SD mouse model [6].

Human native $\beta$-hexosaminidases have been purified from liver [7-11], kidney [12], brain [10], and placenta [13-15]. On the other hand, human $\beta$-hexosaminidases have been recombinantly produced in CHO [5, 16], HeLa [17], and NG141 and NG125 cell lines [18], as well as in insect cells $[17,19,20]$ and yeast (O. minuta and Pichia pastoris KM71H) [21-23]. Native enzymes have been used for structural and biochemical characterization, and in vivo and in vitro GM2 degradation assays [7, 12, 24, 25]. However, recombinant hexosaminidases have not been completely characterized under different $\mathrm{pH}$ or temperature conditions.

Human $\beta$-hexosaminidases extracted from human liver have a molecular weight between 100 and $103 \mathrm{kDa}$ [7]. However, Hex-S extracted from brain and liver displayed a molecular weight of 152 and $154 \mathrm{kDa}$, respectively [10]. The estimated molecular weight of Hex-A and Hex-B produced in $\mathrm{CHO}$ and HeLa cells was between 63 and $69 \mathrm{kDa}[5,17]$. Last, mutated Hex-A produced in NG141 and NG125 cell lines showed a molecular weight of $49 \mathrm{kDa}$ [18]. Furthermore, reported isoelectric point $(p I)$ for human $\beta$-hexosaminidases are 5.4 and 4.2 for Hex-A and Hex-S, respectively $[7,26]$, while for Hex-B it may vary between 7.1 and $7.9[12,26]$. These Hex-B $p I$ values contrast with those reported for the Hex-B sub-subunits (i.e $\beta \mathrm{a}$ and $\beta \mathrm{b}$ ), which may vary from 4.5 to 5.0 , and from 5.3 to 6.0 for $\beta$ a and $\beta$ b, respectively $[13,25]$.

A growing number of studies have revealed the possibility to produce active and therapeutic forms of lysosomal proteins in microorganisms [27]. Previously, we reported the production of active human lysosomal enzymes in P.pastoris and Escherichia coli [28-31]. In this work, we carried out the production of the recombinant human lysosomal $\beta$-hexosaminidases (rhHex-A, rhHex-B, rhHex-S) in the methylotrophic yeast $P$. pastoris GS115, and the effect of temperature and $\mathrm{pH}$ on the stability of the recombinant enzymes was also evaluated. These results represent valuable information towards the use of P. pastoris in the development of an ERT for GM2 Gangliosidoses.

\section{Materials and methods}

\section{Pichia pastoris GS115 transformation}

cDNA of $\alpha$ - (GenBank AAH84537) and $\beta$ - (GenBank AAH17378) subunits of human $\beta$-hexosaminidases were codon-optimized for Pichia sp. expression. Optimized cDNA of $\alpha$-and $\beta$-subunits were designed to encode recombinant $\beta$-hexosaminidases 
with a 6x-His tag at the N-terminal, and synthesized by GeneArt ${ }^{\mathbb{R}}$ (Life Technologies Corporation). Optimized cDNAs were inserted downstream of the Saccharomyces cerevisiae $\alpha$-factor secretion signal present in the pPIC9K vector (Life Technologies Corporation) to produce pPIC9k-alpha and pPIC9k-beta expression vectors. These vectors were confirmed by restriction analysis. To transform competent $P$. pastoris GS115 cells (Life Technologies Corporation) vectors were linearized with Sall and PmeI, respectively and electroporated using a Gene Pulser Xcell ${ }^{\mathrm{TM}}$ Electroporation System (Bio-Rad Laboratories) at $1400 \mathrm{~V}$ y 200 S. P. pastoris GS115 was transformed independently with each subunit (pPIC9k-alpha or pPIC9k-beta) or co-transformed with both subunits. As a control, P. pastoris GS115 was transformed with a linearized empty pPIC9K vector. Transformed clones were selected using minimal dextrose medium (MD: $1.34 \%$ yeast nitrogen base (YNB), 4 x 10-5\% biotin, $2 \%$ D-glucose). All procedures were carried out using standard molecular biology protocols [32].

Gene insertion for $\alpha$-subunit (241 bp amplicon) was confirmed by PCR using the primers $5^{\prime}$-gtttcctctgctgctcaacc- $3^{\prime}$ and $5^{\prime}$-cggacaacaacaaacactgg- 3 ', and 5'-tcatcgactccccaagattc-3' and 5'-tggagtgtaaacgtgggaca-3' for $\beta$-subunit (155 bp amplicon). Phenotype of P. pastoris clones was confirmed by PCR by using the $A O X 1$ primers FW 5'-gactggttccaattgacaagc-3'and RW 5'-gcaaatggcattctgacatcc-3' (Life Technologies Corporation), as reported by Ayra et. al. [33]. All PCR reactions were carried out as follows: $94{ }^{\circ} \mathrm{C} 1 \mathrm{~min}$ denaturation, $55^{\circ} \mathrm{C} 1 \mathrm{~min}$ annealing, and $72{ }^{\circ} \mathrm{C}$ $1 \mathrm{~min} / \mathrm{kb}$ extension, for 30 to 35 cycles.

\section{Shake flask cultures}

P. pastoris clone screening was carried-out in 10 and $100 \mathrm{~mL}$. P. pastoris GS115/ pPIC9k-alpha (rhHex-S), P. pastoris GS115/pPIC9k-beta (rhHex-B), and P. pastoris GS115/pPIC9k-alpha/beta (rhHex-A) clones were grown in YPD (1\% w/v yeast extract, $2 \% \mathrm{w} / \mathrm{v}$ peptone, $2 \%$ dextrose $\mathrm{w} / \mathrm{v}$ ) for $48 \mathrm{~h}$ at $28{ }^{\circ} \mathrm{C}$ and $250 \mathrm{r}$.p.m. Cells were harvested by centrifugation and the pellet was resuspended in BMG medium (100 mM potassium phosphate $\mathrm{pH}$ 6.0, $1.34 \% \mathrm{YNB}, 4 \times 10-5 \%$ biotin, $1 \%$ glycerol) and cultured for $24 \mathrm{~h}$ at $28{ }^{\circ} \mathrm{C}$ and 250 r.p.m. Last, cells were recovered as previously described and resuspended in BMM $(100 \mathrm{mM}$ potassium phosphate $\mathrm{pH}$ 6.0, $1.34 \%$; YNB, $4 \times 10^{-5} \%$; biotin $1 \%$ glycerol, $0.5 \%$ methanol) and cultured for $144 \mathrm{~h}$ at $28{ }^{\circ} \mathrm{C}$ and 250 r.pm. Methanol was added every $24 \mathrm{~h}$ to maintain a final concentration of $0.5 \%$. P. pastoris transformed with an empty pPIC9K vector was used as negative expression control, and was cultured under the conditions described above. Aliquots were taken every $24 \mathrm{~h}$ and stored at $-20{ }^{\circ} \mathrm{C}$ until their use. The cell density was determined by using a previously described calibration curve $\left(\mathrm{g} . \mathrm{L}^{-1}=0.528 \times \mathrm{OD}_{600 \mathrm{~nm}} \times 0.619, \mathrm{r}^{2}=0.98\right)[28]$.

\section{Bioreactor culture}

Clones with the highest activity at shake flask scale were evaluated at $1.65 \mathrm{~L}$ scale in a $3.7 \mathrm{~L}$ Bioengineering reactor. Cultures were prepared in a modified FM22 saline medium (composition per liter: $25.74 \mathrm{~g} \mathrm{KH}_{2} \mathrm{PO}_{4}, 3 \mathrm{~g}(\mathrm{NH} 4)_{2} \mathrm{SO}_{4}, 8.58 \mathrm{~g} \mathrm{~K} 2 \mathrm{SO}_{4}$, $0.6 \mathrm{~g} \mathrm{CaSO}_{4} 2 \mathrm{H}_{2} \mathrm{O}, 40 \mathrm{~g}$ glycerol, $7.02 \mathrm{~g} \mathrm{MgSO}_{4} 7 \mathrm{H}_{2} \mathrm{O}, 4 \times 10^{-5} \%$ biotin, $1 \mathrm{~mL}$ mineral traces, and $5 \mathrm{~mL}$ silicone) $[34,35]$. Protein production was performed in three phases: i) a batch culture with glycerol to achieve $40 \mathrm{~g} \cdot \mathrm{L}^{-1}$ biomass, ii) a fed-batch culture 
with glycerol to achieve $60 \mathrm{~g} . \mathrm{L}^{-1}$ biomass, and iii) a fed-batch induction phase with methanol. Methanol concentration was maintained at $0.5 \pm 0.005 \%$ by using an ALCOSENS probe (Heinrich Frings GmbH \& Co. KG), with an automatic feed control. Cultures were carried out at $\mathrm{pH}$ of 5.0 (maintained with $7 \%$ ammonium hydroxide) $28^{\circ} \mathrm{C}$, and under limited oxygen conditions.

\section{Crude protein extraction and enzyme purification}

Recombinant proteins were purified from culture medium thanks to $\alpha$-factor secretion signal presence. Culture medium (crude extract) was filtered sequentially through paper Whatman No. 1 and 42, Pellicon XL Filter Module Durapore $0.45 \mu \mathrm{m}-50 \mathrm{~cm}^{2}$ (Merck/Millipore), and $0.22 \mu \mathrm{m}$ polyether sulphone membrane (Merck/Millipore). Permeate was ultrafiltered in a Stirred Ultrafiltration Cell through a $100 \mathrm{kDa}$ cut-off Ultracel ${ }^{\circledR}$ ultrafiltration disc (Merck/Millipore). Subsequently, samples were dialyzed under previously established conditions: i) $25 \mathrm{mM}$ acetate buffer $\mathrm{pH} 5.5$ for rhHex-S, ii) $25 \mathrm{mM}$ acetate buffer $\mathrm{pH} 5.0$ for rhHex-B, or iii) $25 \mathrm{mM}$ or $10 \mathrm{mM}$ phosphate buffer $\mathrm{pH} 6.0$ for rhHex-A. Dialyzed samples were purified by using a low-pressure chromatography system (BioLogic ${ }^{\mathrm{TM}}$ LP System, Bio-Rad Laboratories), using Q-Sepharose Fast Flow column (Amersham Biosciences) for rhHex-S, Q-Sepharose Fast Flow or Macro-Prep DEAE Support (Bio-Rad Laboratories) for rhHex-A, while rhHex-B was purified by using Macro-Prep High S Support. Protein elution was performed by a 0 to $0.5 \mathrm{M} \mathrm{NaCl}$ linear gradient. Fractions with enzyme activity were concentrated by Amicon ultracentrifugal filters Ultracel ${ }^{\circledR} 50 \mathrm{~K}$ (Merck/Millipore) and stored at $-20{ }^{\circ} \mathrm{C}$ until their use. All procedures were carried out at $4{ }^{\circ} \mathrm{C}$. Protein purification was monitored by SDS-PAGE under reducing conditions and hexosaminidase enzyme activity.

\section{Amino acid sequencing}

Recombinant proteins were separated by SDS-PAGE [36], electro blotted to PVDF membranes (Millipore) [37], and visualized with Coomassie blue stain. The proteins of interest were excised from the membrane and subjected to automated Edman sequencing on a Procise 492 protein sequencer controlled by Procise software (version 5.1) [38] at the Protein Chemistry Laboratory, Texas A\&M University.

\section{Tryptic fragment digestion analysis of purified proteins by MALDI-TOF}

Recombinant proteins were analyzed by SDS-PAGE [36], and the $100 \mathrm{kDa}$ bands from rhHex-A and rhHex-S, and the $200 \mathrm{kDa}$ band from rhHex-B were de-stained and treated as previously described [39]. Tryptic digested peptides were processed by MALDI-TOF Mass Spectrometer (Shimadzu/Kratos). The results were analyzed through Peptide Mapping (Thermo Fisher) and ProFound (http://prowl.rockefeller. edu/prowl-cgi/profound.exe). Tryptic fragment digestion analysis was done at the Protein Chemistry Laboratory, Texas A\&M University.

\section{Hexosaminidase activity assay}

Hexosaminidase activity was assayed by using 4-methylumbelliferyl- $\beta$-D-acetylglucosaminide (MUG, Sigma-Aldrich) or 4-methylumbelliferyl- $\beta$-D-acetylglucosaminide sulfate (MUGS, Calbiochem) substrates, as previously described 
$[40,41]$. Human leukocyte $\beta$-hexosaminidase activity was assayed in samples from healthy individuals following the protocol described by Shapira et. al. (1989) [40]. A $2.5 \mathrm{mM}$ MUG substrate was used dissolved in citrate-phosphate at $\mathrm{pH} 4.4 .10 \mathrm{mM}$ MUGS substrate was dissolved in deionized water. Reaction was stopped by $0.2 \mathrm{M}$ glycine/0.2 $\mathrm{M} \mathrm{Na}_{2} \mathrm{CO}_{3}$ solution $\mathrm{pH} 9.8$ addition. Released 4-methylumbelliferone (MU) fluorescence was quantified in a Turner Fluorometer at 450/350 nm emission/ excitation. One unit $(\mathrm{U})$ was defined as the amount of enzyme hydrolyzing $1 \mathrm{nmol}$ of substrate per hour. Specific hexosaminidase activity was expressed as $\mathrm{U}_{\mathrm{mg}} \mathrm{m}^{-1}$ of total protein determined by Lowry assay, and volumetric activity as $\mathrm{U} . \mathrm{mL}^{-1}$.

\section{Characterization of recombinant hexosaminidases}

pH effect. The effect of $\mathrm{pH}$ on the activity of recombinant hexosaminidases was evaluated at 3.5, 4.0, 5.0, 5.5, 6.0, 7.0, and 7.5. Each purified enzyme was incubated with $25 \mathrm{mM}$ sodium citrate, or $25 \mathrm{mM}$ phosphate buffer for acidic and basic $\mathrm{pH}$ values respectively. Samples were incubated at $37^{\circ} \mathrm{C}$ for $1 \mathrm{~h}$. After incubation enzyme activity was measured as described above, using MUGS for rhHex-A, and MUG for rhHex-B and rhHex-S.

Temperature effect. The effect of temperature on enzyme activity was carried out at the $\mathrm{pH}$ of maximum activity for each enzyme (i.e. $\mathrm{pH} 5.0$ for rhHex-A; $\mathrm{pH} 4.0$ for rhHex-S, and $\mathrm{pH} 4.5$ for rhHex-B). Recombinant enzymes were incubated at $(4,37$, and 45) ${ }^{\circ} \mathrm{C}$ during $2,4,6,8,10,12,24,48$, and $72 \mathrm{~h}$. After incubation enzyme activity was measured as previously described, using MUGS for rhHex-A, and MUG for rhHex-B and rhHex-S.

Stability in buman serum: To assess the stability of the recombinant hexosaminidases in human serum $1 \mu \mathrm{L}$ of each purified enzyme was incubated with $49 \mu \mathrm{L}$ of pooled human serum from healthy individuals. The mixture was incubated for 1, 3, 6, and $24 \mathrm{~h}$ at $37^{\circ} \mathrm{C}$. Human serum not spiked with recombinant enzyme was used as control and incubated under the described conditions. After incubation enzyme activity was measured as described above, using MUG substrate. Serum samples from healthy individuals were obtained after signed consent, and approved by the Research and Ethics Committee of the School of Science at Pontificia Universidad Javeriana.

\section{Results and discussion}

\section{Pichia pastoris GS115 recombinant hexosaminidase production}

Five P. pastoris GS115 clones for each enzyme rhHex-A, rhHex-B, and rhHex-S, were randomly selected and screened at $10 \mathrm{~mL}$. At this scale, the highest enzyme activity levels determined with MUG substrate were 208.7, 145.4, 1,717.5 U $\cdot \mathrm{mL}^{-1}$, for rhHex-A, rhHex-B, and rhHex-S, respectively. Three P. pastoris methanol phenotypes related to non-deletions $\left(\mathrm{Mut}^{+}\right)$, one deletion $\left(\mathrm{Mut}^{\mathrm{S}}\right)$, or two deletions (Mut) in AOX genes promoters have been reported. Mut mutants grow in methanol at a slow rate and need much less methanol during the induction phase compared with $\mathrm{Mut}^{+}$mutants [42]. As expected, all $\beta$-hexosaminidase clones evaluated displayed a genotype compatible with $\mathrm{Mut}^{+}$phenotype, as well as the presence of $\alpha-$, $\beta$-, or $\alpha / \beta$ subunit $\mathrm{cDNA}$. Clones with the highest volumetric activity levels were scaled-up to $100 \mathrm{~mL}$ and $1.65 \mathrm{~L}$ scales. 
Recombinant $\beta$-hexosaminidase shake flask level production was carried-out in $100 \mathrm{~mL}$ with $0.5 \%$ methanol during $144 \mathrm{~h}$ induction. For rhHex-A, the highest volumetric and specific activities, determined with MUG substrate were observed at $72 \mathrm{~h}$ of induction with values of $182.2{\mathrm{U} \cdot \mathrm{mL}^{-1}}$ and 1,207.6 $\mathrm{U} \cdot \mathrm{mg}^{-1}$, respectively. The highest levels of volumetric and specific activities of rhHex-B were observed at $72 \mathrm{~h}$ of induction, with values of $19,257.3 \mathrm{U} \cdot \mathrm{mL}^{-1}$ and $11563.3 \mathrm{U} \cdot \mathrm{mg}^{-1}$. Last, for thHex-S the highest volumetric and specific activities were observed at $96 \mathrm{~h}$ of induction with values of $8,173.7 \mathrm{U} \cdot \mathrm{mL}^{-1}$ and $36,292.06 \mathrm{U} \cdot \mathrm{mg}^{-1}$, respectively. P. pastoris transformed with the empty pPIC9K vector (negative control) showed a maximum total $\beta$-hexosaminidase activity of $3.2 \mathrm{U} \cdot \mathrm{mg}^{-1}$, which was notably lower compared with clones expressing recombinant human $\beta$-hexosaminidases. Furthermore, Uniprot and GenBank search did not identify $\beta$-hexosaminidase-like proteins in $P$. pastoris CBS 7435 (Taxonomy ID 981350), DMSZ 70382 (Taxonomy ID 638632), and GS115 (Taxonomy ID 644223). Taken together, these results demonstrate $\beta$-hexosaminidase activity detected in clones expressing rhHex-A, rhHex-B, and rhHex-S was due the result of human Hex cDNAs insertion and not to endogenous $P$. pastoris $\beta$-hexosaminidases-like enzymes presence. Furthermore, these results show substrate specificity used to follow-up recombinant human $\beta$-hexosaminidases production.

As expected, at $1.65 \mathrm{~L}$ specific activities values were increased, since growth and induction conditions $(\mathrm{pH}$, temperature, aeration, and feed rate) were carefully controlled, improving heterologous protein production [43]. We evaluated different concentrations of glycerol and methanol during batch and fed-batch stages, respectively. The results showed that $40 \mathrm{~g} \cdot \mathrm{L}^{-1}$ glycerol and $0.5 \% \mathrm{v} / \mathrm{v}$ methanol, yielded highest biomass concentration and enzyme activity levels for the recombinant $\beta$-hexosaminidases. Thus, all bioreactor experiments were performed with $0.5 \%$ $\mathrm{v} / \mathrm{v}$ methanol, resulting in final biomass between 120 to $190 \mathrm{~g} \mathrm{~L}^{-1}$, and total protein concentration of $1.6,1.4$, and $2.5 \mathrm{mg} \cdot \mathrm{mL}^{-1}$ for clones expressing rhHex-A, rhHex-B, and rhHex-S, respectively. Dissolved oxygen (DO) was maintained below $10 \%$ according to microorganism requirements. Limited oxygen conditions have been previously described to contribute in cell lysis reduction and heterologous enzyme yield production increase [44]. Furthermore, it has been demonstrated that cultures under limited oxygen conditions lead to higher yields of protein production than those with high oxygen supply $[45,46]$. As a case in point, production of recombinant human iduronate-2-sulfatase in P. pastoris GS115, a recombinant human lysosomal enzyme was increased under oxygen-limited conditions [47].

The highest specific and volumetric enzyme activities at $1.65 \mathrm{~L}$ were 13,124.1 $\mathrm{U} \cdot \mathrm{mg}^{-1}$ and $25,762.6 \mathrm{U} \cdot \mathrm{mL}^{-1}$ for rhHex-A, respectively. For rhHex-B at this scale,

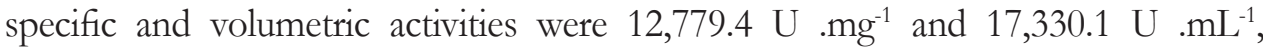
respectively. Last, rhHex-S at $24 \mathrm{~h}$ of induction had a specific activity of 21,025.9 $\mathrm{U} . \mathrm{mg}^{-1}$. Nevertheless, this result was not consistent with low protein concentration and volumetric activity observed at this time. Therefore, 14,606.0 U . $\mathrm{mg}^{-1}$ and 15,556.1 U $\cdot \mathrm{mL}^{-1}$ at $96 \mathrm{~h}$ were considered the highest specific and volumetric activities for rhHex-S, respectively (Figure 1). These enzyme activity results were determined with non-sulfated substrate (MUG) and were between 25- and 50-fold higher compared with those obtained from leukocyte samples from healthy individuals processed in our laboratory (total $\beta$-hexosaminidase specific activity 

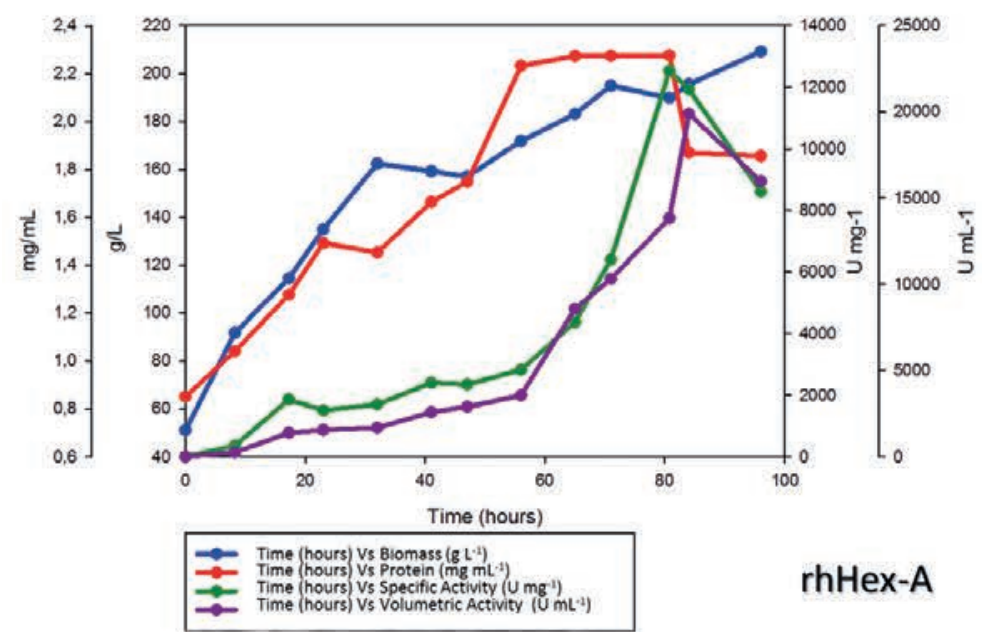

rhHex-A
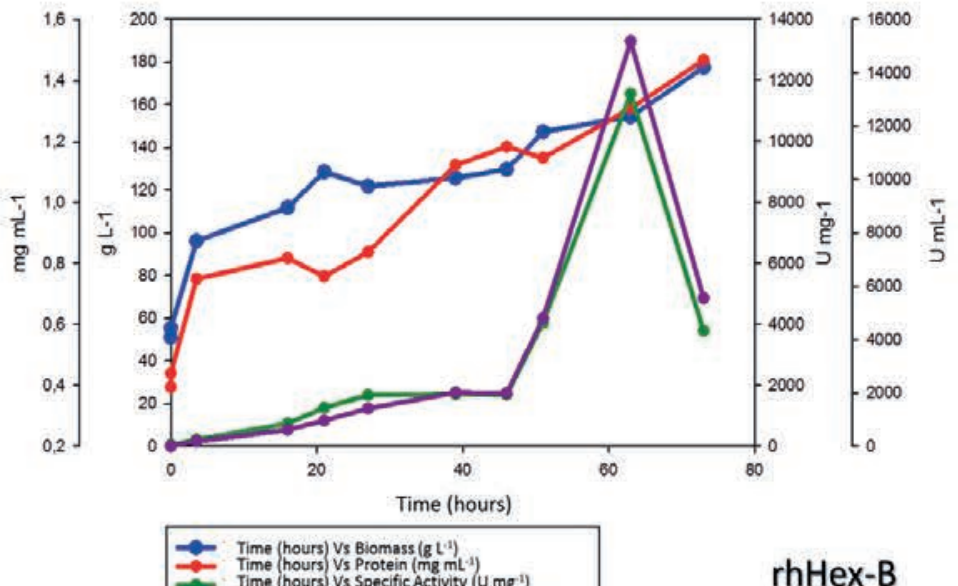

- Time (hours Vs Specific Activity $\left(\mathrm{mg}^{-1}\right) \quad$ rhHex-B
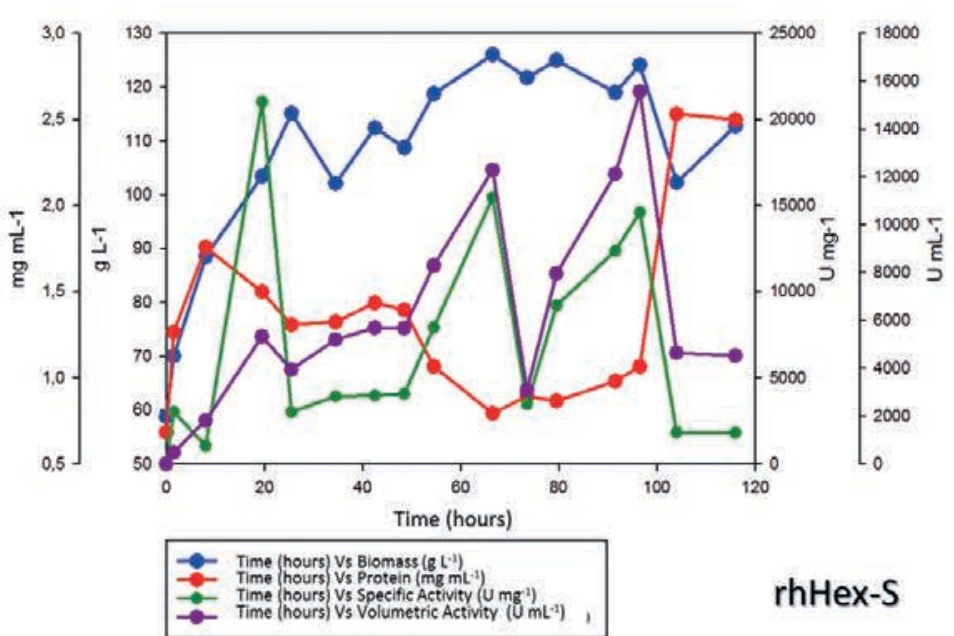

rhHex-S

Figure 1. Production of rhHex-A (A), rhHex-B (B), and rhHex-S (C) in 1.65 L. Production of recombinant enzymes was induced with $0.5 \% \mathrm{v} / \mathrm{v}$ methanol. Outer Left axis: protein concentration as determined by Lowry method $(\mathrm{mg} / \mathrm{mL})$. Inner left axis: biomass dry weight $(\mathrm{g} / \mathrm{L})$. Inner right axis: Specific enzyme activity in $\mathrm{U} \cdot \mathrm{mg}^{-1}$. Outer right axis: Volumetric enzyme activity in $\mathrm{U} \cdot \mathrm{mL}^{-1}$. Data is an average of duplicate cultures.n 
$388.18 \pm 10 \mathrm{U} \cdot \mathrm{mg}^{-1}$ and volumetric activity $\left.431.02 \pm 10 \mathrm{U} \mathrm{mL}^{-1}\right)$. Akeboshi et. al. [22], using the methylotrophic yeast Ogataea minuta, reported specific activities of 51,000 and 29,000 $\mathrm{U} \cdot \mathrm{mg}^{-1}$ with non-sulfated and sulfated substrates, respectively. In this sense, the enzyme activity rhHex-A produced in P. pastoris at $1.65 \mathrm{~L}$ was approximately 3.9-fold lower than that reported for $O$. minuta at $4 \mathrm{~L}$ scale. Since these enzyme activity levels are in the same order of magnitude $\left(10^{3} \mathrm{U} \cdot \mathrm{mg}^{-1}\right)$ than that of O. minuta Hex-A, these results determine P. pastoris potential as an expression system for recombinant Hex-A. Expression of recombinant Hex-B in Saccharomyces cerevisiae showed that the enzyme was directed to the vacuole and was active despite a different glycosylation pattern [48]. Nevertheless, rhHex-B activity produced in this study was $\sim 8,000$-fold higher compared with that reported for $S$. cerevisiae $\left(1.6 \mathrm{U} \cdot \mathrm{mg}^{-1}\right)$ [48]. Recently, production of recombinant Hex-B in P. pastoris $\mathrm{KM} 71 \mathrm{H}$ was described, yet activity results are not comparable since enzyme activity assay substrate ( $\mathrm{p}$-nitrophenyl 2 -acetamido-2-deoxy- $\beta$-d-glucopyranoside) was different to that used in this study (4-methylumbelliferyl- $\beta$-D-acetyl-glucosaminide) [23]. Last, for recombinant Hex-S Akeboshi et. al. [22] reported its production during recombinant Hex-A production, where $O$. minuta yeast was co-transformed both with HEXA and HEXB genes. Although this recombinant Hex-S represented $74 \%$ of total isozymes produced, they did not describe Hex-S activity values nor recombinant enzyme characterization [22]. Therefore, the present study represents the first report for production, purification, and characterization of recombinant Hex-S in yeast.

\section{Purification of recombinant Hexosaminidases}

Although human $\beta$-hexosaminidases cDNAs were designed to encode an $\mathrm{N}$-terminal $6 \mathrm{x}$ His-tag, after several attempts of purification through His-tag affinity chromatography, it was not possible to obtain the purified recombinant enzymes. These results were associated with a probable loss of 6xHis-tag through proteolytic processing during enzyme maturation. In fact, Edman protein sequencing confirmed lack of $\mathrm{N}$-terminal 6x-His tag for all three recombinant $\beta$-hexosaminidases. Hence, recombinant $\beta$-hexosaminidases were purified by ion exchange chromatography, according to reported isoelectric points for hexosaminidases extracted from human tissues [7, 12, 26]. rhHex-A, rhHex-B, and rhHex-S clones were cultured in $1.65 \mathrm{~L}$ and harvested at the highest production time for enzyme purification. rhHex-A and rhHex-S were purified by anion exchange chromatography at $\mathrm{pH} 6.0$ and 5.5, respectively; while rhHex-B was purified by cation exchange chromatography at $\mathrm{pH}$ 5.0.

Final specific enzyme activity for purified rhHex-A, rhHex-B, and rhHex-S was 1.35 x $10^{6} ; 1.27 \times 10^{6}$; and $1.39 \times 10^{6} \mathrm{U} \mathrm{mg}^{-1}$, respectively. Results showed a 136-, 127-, and 139-fold of purification for rhHex-A, rhHex-B, and rhHex-S, respectively (Table 1). Reports in literature are limited regarding $\beta$-hexosaminidase purification, and most reports are derived from human data. For instance, Conzelmann et. al. [9], reported an enzyme activity of $5.5 \times 10^{6} \mathrm{U} \cdot \mathrm{mg}^{-1}$ after purification of Hex-A (from human liver of a patient with $\mathrm{GM} 2$ variant $\mathrm{AB}$ ) by concanavalin affinity chromatography and DEAE cellulose. Nevertheless, they did not report enzyme activity values for Hex-B purified from human liver, due to low protein concentration. Tallman et. al. [49], after six purification steps for human placenta $\beta$-hexosaminidases, reported enzyme activity values of $30.6 \times 10^{6}$ and $28.1 \times 10^{6} \mathrm{U}^{-\mathrm{mg}^{-1}}$ for Hex-A and Hex-B, respectively. Regarding the recombinant production of human $\beta$-hexosaminidases, rhHex-B 
Table 1. Purification of rhHexosaminidases produced in Pichia pastoris.

\begin{tabular}{lccccc}
\hline \multicolumn{1}{c}{ Sample } & $\begin{array}{c}\text { Total Protein } \\
(\mathrm{mg} / \mathrm{mL})\end{array}$ & $\begin{array}{c}\text { Total activity U } \\
(\mathrm{nmol} / \mathrm{h}) \mathbf{1 0} \mathbf{1 0}^{6}\end{array}$ & $\begin{array}{c}\text { Specific activity } \\
(\mathrm{nmol} / \mathrm{mg} / \mathrm{h})\end{array}$ & \% yield & fold \\
\hline $\begin{array}{l}\text { rhHex-A } \\
\begin{array}{l}\text { Crude } \\
\text { extract }\end{array}\end{array}$ & 2716.60 & 34.28 & 0.01 & 100 & 1 \\
$\begin{array}{l}\text { Ultrafiltration } \\
\text { retentate }\end{array}$ & 150.74 & 19.36 & 0.13 & 56 & 13 \\
$\begin{array}{l}\text { Purified } \\
\text { protein }\end{array}$ & 12.96 & 17.59 & 1.36 & 51 & 136 \\
$\begin{array}{l}\text { rhHex-B } \\
\text { Crude } \\
\text { extract }\end{array}$ & 1890.00 & 19.56 & 0.01 & 100 & 1 \\
$\begin{array}{l}\text { Ultrafiltration } \\
\text { retentate }\end{array}$ & 325.15 & 6.53 & 0.02 & 33 & 2 \\
$\begin{array}{l}\text { Purified } \\
\text { protein } \\
\text { rhHex-S }\end{array}$ & 4.20 & 5.33 & 1.27 & 27 & 127 \\
$\begin{array}{l}\text { Crude } \\
\text { extract }\end{array}$ & 1605.00 & 23.33 & 0.01 & 100 & 1 \\
$\begin{array}{l}\text { Ultrafiltration } \\
\text { retentate }\end{array}$ & 72.73 & 15.08 & 0.21 & 65 & 21 \\
$\begin{array}{l}\text { Purified } \\
\text { protein }\end{array}$ & 9.60 & 13.38 & 1.39 & 57 & 139 \\
\hline
\end{tabular}

produced in insect cells and purified by two chromatographic steps showed a final enzyme activity of $6.5 \times 10^{6} \mathrm{U} \cdot \mathrm{mg}^{-1}$ [20]; while rhHex-A produced in O. minuta and purified by affinity chromatography showed a final activity of $1.4 \times 10^{6} \mathrm{U}_{\mathrm{mg}} \mathrm{mg}^{-1}$ [21]. Although in this study a one-step chromatography purification process was employed, purified rhHex-A and rhHex-B produced in P. pastoris GS115 showed similar enzyme activity levels to those of the recombinant enzymes produced in other expression systems, but lower than those levels reported for native enzymes. On the other hand, specific activity of purified rhHex-S was 50-fold higher than that reported by Potier et. al. [10] for liver Hex-S (26820 U .mg-1), and considerably higher than that purified from brain (1494 $\left.\mathrm{U} \cdot \mathrm{mg}^{-1}\right)$. Last, specific activity of purified rhHex-S was 2.2-fold lower than that reported by Hepbildikler et. al. $\left(3.1 \times 10^{6} \mathrm{U}_{\mathrm{mg}} \mathrm{mg}^{-1}\right)$ produced in insect cells [19].

Since $P$. pastoris transformed with $\alpha$ - and $\beta$-Hex cDNAs (rhHex-A) can produce the three isozymes (rhHex-A, rhHex-B, and $\mathrm{rhHex}-\mathrm{S}$ ), we estimated the presence of these enzymes within the rhHex-A crude extract and eluted fractions from anionic chromatography (DEAE sepharose) (Figure 2). Compared to other $\beta$-hexosaminidases, recombinant enzymes produced in this study showed a different pattern using DEAE sepharose chromatography. As observed in Figure 2A, rhHex-B and rhHex-A were detected in lower proportion in the non-bound protein (NBP) than in eluted protein (EP) fractions measured with non-sulfated substrate (MUG). The evaluation of the 

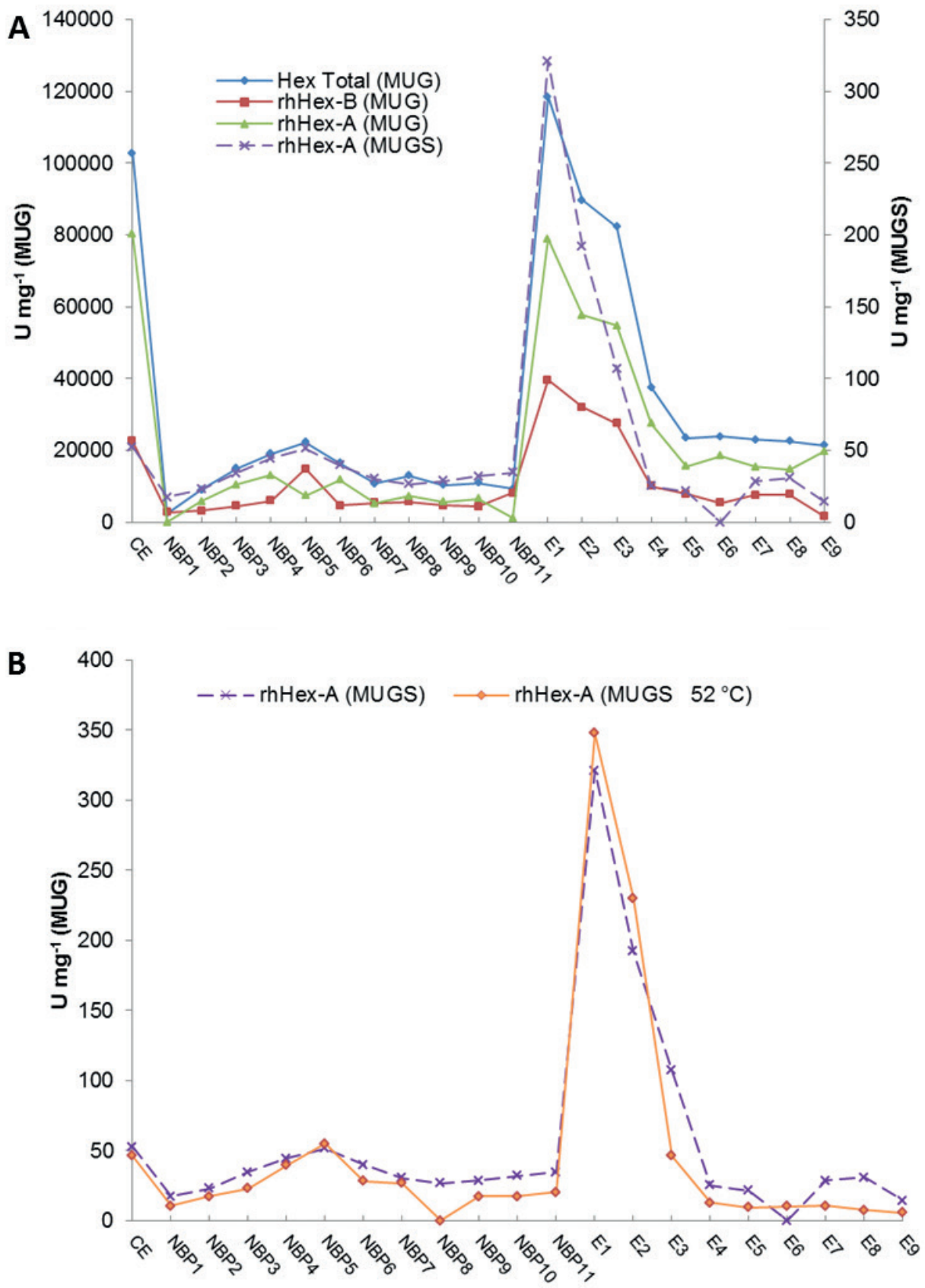

Figure 2. rhHex-A:rhHex-B ratio in rhHex-A crude extract. rhHex-A:rhHex-B ratio from rhHexA crude extract was determined by DEAE anion exchange chromatography. A. CE: rhHexA crude extract; NBP: non-bound protein fractions; E: eluted protein fractions. Total rhHex (red line): activity assayed with MUG substrate; $\mathrm{rhHexB}$ (green line): activity assayed with MUG substrate after $52^{\circ} \mathrm{C}$ inactivation; rhHex-A (MUG) (blue line): difference between total rhHex and rhHex-B activity assayed with MUG substrate; rhHex-A (purple dotted-line): activity assayed with MUGS substrate. B. Presence of rhHex-S within rhHexA crude extract was ruled out by measuring $\beta$-hexosaminidase activity with MUGS substrate with or without sample inactivation at $52^{\circ} \mathrm{C}$, according to rhHex-S thermostability profile.

activity assay using the MUGS substrate, with and without $52{ }^{\circ} \mathrm{C}$ inactivation (see Figure 5 rhHex-S thermostability), suggested rhHex-S is not present within the rhHexcrude extract (Figure 2B). These results contrast with previous reports, using DEAE 
sepharose, which determined Hex-B and Hex-A/Hex-S were obtained in NBP and EP fractions, respectively [12, 26, 49-51]. Taking in to account these results, the HexA:Hex-B ratio was established using EP fraction specific activity levels measured with MUG substrate, obtaining a Hex-A:Hex-B ratio of 2.17. Although the ratio was calculated in a different manner compared with previous reports, this value was similar to that reported by Okochi et. al. [52] for $\beta$-hexosaminidases purified from kidney (2.5 to 4.52), and higher than that reported for $\beta$-hexosaminidases purified from placenta ( 0.89 to 1.24 ). Furthermore, in this study rhHex-A represents a $67 \%$ of total isozymes present in the rhHex-A crude extract, which was 3-fold higher than that reported for the recombinant Hex-A produced in 0 . minuta (about $23 \%$ of the total $\beta$-hexosaminidases after DEAE purification process [22].

Molecular weights of most tissue extracted proteins have been established using gel filtration chromatography. Hex-A purified from human placenta displayed a molecular weight of $112.5 \mathrm{kDa}$ [15]; while molecular weights between 100 and $110 \mathrm{kDa}$ have been reported for human liver purified enzyme [7, 8]. Similar results were reported for Hex-B purified from liver and placenta, with a molecular weight between 108 and $112 \mathrm{kDa}$, respectively. In addition, a $103 \mathrm{kDa}$ Hex-S was described in human liver [7]. In contrast, Potier et. al. reported for Hex-S, purified from liver and brain, a molecular weight of 154 and $152 \mathrm{kDa}$, respectively [10]. In this study, using a SDS-PAGE analysis under reducing conditions, for rhHex-B bands of $\sim 200 \mathrm{kDa}$ were observed, and for rhHexA and rhHex-S of $\sim 100 \mathrm{kDa}$ (Figure 3A). This high molecular weight could be mainly associated with differences in $\mathrm{N}$-glycosylations among purified proteins [22, 53]. For instance, for recombinant proteins produced in P. pastoris, high mannose N-glycans (Man8-12) have been described [54, 55], while low mannose N-glycans (Man5) have been described for proteins produced in CHO cells [54]. Although Akeboshi et. al. determined two bands at 46 and $43 \mathrm{kDa}$ after EndoH treatment, we consider that the marked difference in molecular weight observed between $\beta$-hexosaminidases expressed in P. pastoris GS115 and those purified from other sources (native or recombinant) could be also associated with interactions between subunits through non-covalent bonds that may prevent dissociation under reducing conditions and favor protein aggregate formation [56].

Immunodetection of recombinant $\beta$-hexosaminidases was attempted by Westernblot using commercial antibodies against $\alpha$ - and $\beta$-subunits. After several attempts and Western-blot modifications (e.g. protein and antibodies concentration and incubation times), it was possible to observe faint bands that correlated with those observed in the SDS-PAGE. However, these results did not allow for reliable evidence regarding recombinant protein identity, due to low band intensity (data no shown). Therefore, to confirm recombinant human $\beta$-hexosaminidase identity, SDS-PAGE gel bands obtained under reducing conditions from purified fractions, were analyzed through MALDI-TOF (Figure 3B). Tryptic fragments from the $100 \mathrm{kDa}$ band of rhHex-A sample corresponded with both $\alpha$ - and $\beta$-subunit sequences of human $\beta$-hexosaminidases. Furthermore, tryptic fragments from rhHex-B $(200 \mathrm{kDa})$ and rhHex-S $(100 \mathrm{kDa})$ bands coincided with $\beta$ - and $\alpha$-subunits of human $\beta$-hexosaminidases, respectively.

Taken together, these results confirm recombinant $\beta$-hexosaminidases produced in $P$. pastoris identity and suggest these recombinant $\beta$-hexosaminidases have 


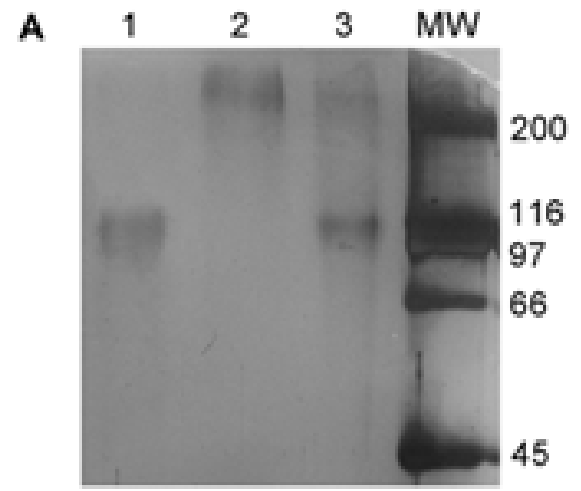

B

\section{Hex-A \\ alpha-subunit}

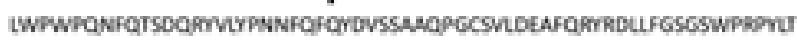

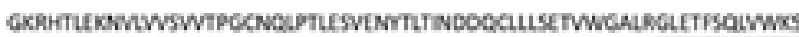

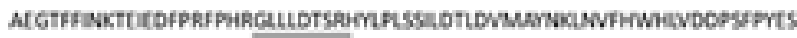

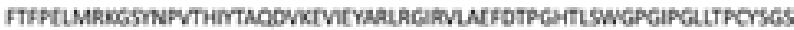
(1)

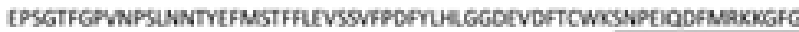
E

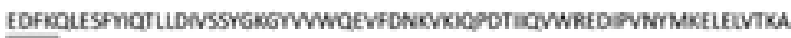

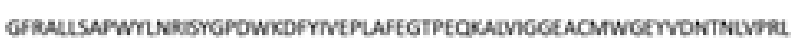

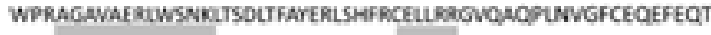

\section{Hex-B}

beta-subunit

ARAPSVSAKPGPALWPLVISVXMTPNLLHLAPEN MSHSONSTAGPSCTLEEAFRRMH

GYFGMXWHHEPAEFQAXTQVCOLIVSITLSECDAFPNISSOESTIUKEPVAVIXA

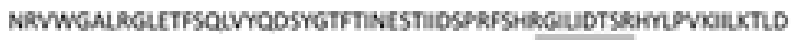

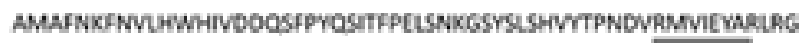

IRVIPEFOTPGHTLSWGKGQXOUTPCYSACNXIOSFGPINPTUNTTYSFUTTFFCISEV

FPDQFIHLGGOEVEFKCWESNPKICOFMROKGFGTDFKXUESFYIXKVDIATINKGSI

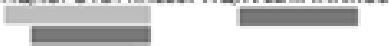

VWQEVFDOKAKLAPGTIVEWWKOSAYPEELSRVTASGFPVISAPWNOUSYGCOWR

KYYKVEPLOFGGTQKQKQLFIGGEACIWGEYDATNLTPRLWPRASANGERLWSSKDV

ROMDDAYDRLTRHECRMNERGIAAOPLYAGYCNHENM

\section{Hex-A \\ beta-subunit}

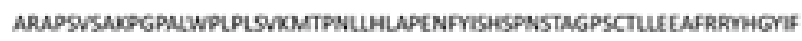

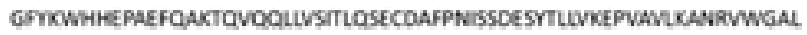

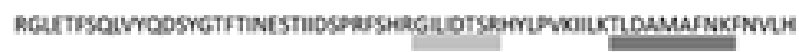

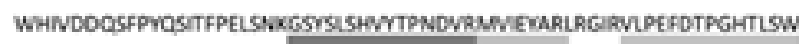

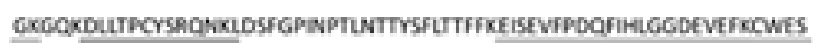

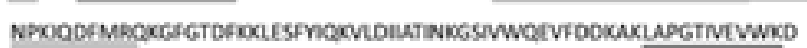

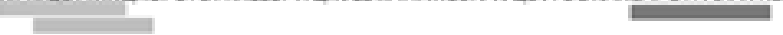
SANPEELSEVTASGFPVISAPWYLDUSYGQDWRKYMKVEPLDFGGTQCQNQLFIGGEACIW

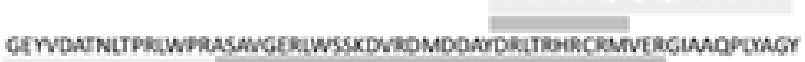
Cleterm

\section{Hex-S alpha-subunit}

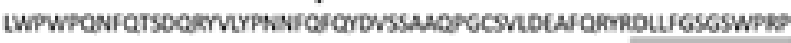
YUGKRHTLEKWVINYSWTPGCNOUPTESVENYTUINDOQCULSETWWGALAGLETFSO

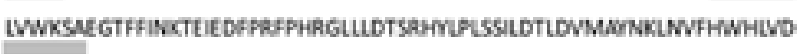

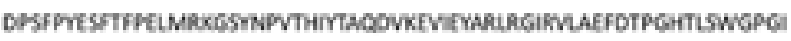
PGUUTPCYSGSEPSGTFGPVNPSLNNTVEFMSTFFLEVSSVFPDFYHLGGOEVDFTCWKSN Pticefmenckgrgtofmus DEVWYMKELEIVTKAGFRALLSAPWYLRISYGPOWKOFYNEPLAFEGTFECKAIVIGGEA

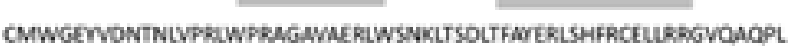
NuGrceoefect

Figure 3. A. SDS-PAGE of purified recombinant hexosaminidases. Polyacrylamide gel was ran under reducing conditions. $10 \mu \mathrm{g}$ of protein was loaded in each lane. Gels were stained with silver nitrate. Lanes 1 to 3 : rhHex-S, rhHex-B, and rhHex-A purified fractions, respectively. B. Analysis of Tryptic fragments of purified proteins by MALDI-TOF. Recombinant proteins were analyzed by SDS-PAGE and gel bands were cut, de-stained and treated to obtain tryptic fragments, followed by MALDI-TOF evaluation. Tryptic fragments from rhHex-A $100 \mathrm{kDa}$ band showed a correspondence with $\alpha$ - and $\beta$-subunits of human $\beta$-hexosaminidases. Bars under amino acid sequences represent peptide fragments identified after MALDI-TOF analysis. The tryptic fragments from the 200 and $100 \mathrm{kDa}$ bands for rhHex-B and rhHex-S, respectively, showed a correspondence with the $\beta$ - and $\alpha$-subunits of human $\beta$-hexosaminidases, respectively. 
different molecular weights than those reported for both native and recombinant $\beta$-hexosaminidases. These results might agree with dimer association description during native hexosaminidase A crystallization [15]. However, further assays are necessary to confirm these results.

\section{Characterization of recombinant Hexosaminidases}

Recombinant $\beta$-hexosaminidases were characterized for their stability at different $\mathrm{pH}$ (3.5 to 7.5 ) and temperature $\left(4^{\circ} \mathrm{C}, 37^{\circ} \mathrm{C}\right.$, and $\left.45^{\circ} \mathrm{C}\right)$ conditions, as well as in human serum. Regarding $\mathrm{pH}$ stability, rhHex-A, rhHex-B, and rhHex-S reduced their activity by $35 \%, 50 \%$ and $15 \%$ of activity respectively at $\mathrm{pH} 3.5$ (Figure 4). rhHex-A depicted its highest activity between $\mathrm{pH} 4.5$ and 5.0, with a reduction between 10 and $55 \%$ at $\mathrm{pH}$ above 5.5 , while at $\mathrm{pH} 4.0$ enzyme activity was reduced by $15 \%$ compared with levels observed at $\mathrm{pH} 5.0$ (Figure 4). On the other hand, rhHex-B showed highest activity at $\mathrm{pH} 4.5$, with a marked reduction at $\mathrm{pH}$ values above $(60 \%)$ or below $(50 \%)$ this $\mathrm{pH}$ (Figure 4). Last, rhHex-S showed the highest activity at $\mathrm{pH}$ 4.0, with an up to $15 \%$ reduction at $\mathrm{pH}$ values below 4.0 and up to 6.0. Nevertheless, a marked activity reduction between 80 and $100 \%$ was observed at $\mathrm{pH}$ greater than 6.0 (Figure 4). There are few reports showing the effect of $\mathrm{pH}$ on enzyme activity for $\beta$-hexosaminidases. However, these results are in agreement with those reported by Geiger et. al. [7], who described a maximum $\mathrm{pH}$ activity in a range from 4.0 to 5.0, for $\beta$-hexosaminidases extracted from liver.

Temperature stability was evaluated up to $72 \mathrm{~h}$ at 4,37 and $45^{\circ} \mathrm{C}$ (Figure 5). Under these conditions, rhHex-A did not show a significant reduction in enzyme activity at 4 and $37^{\circ} \mathrm{C}$ throughout the evaluated time $(72 \mathrm{~h})$. In contrast, at $45^{\circ} \mathrm{C}$ enzyme remained stable during the first $10 \mathrm{~h}$, after which a marked reduction was observed reaching

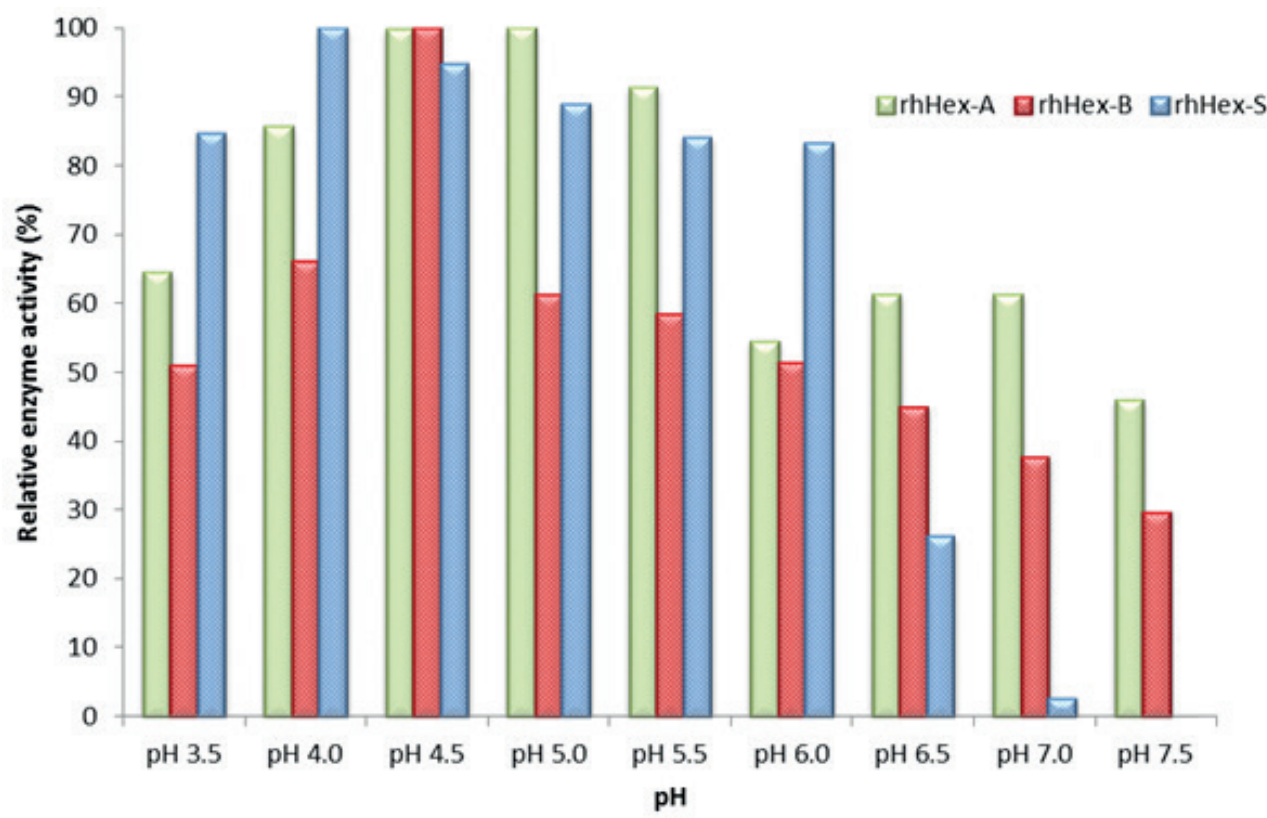

Figure 4. Effect of $\mathrm{pH}$ on recombinant hexosaminidase enzyme activity. Enzyme activity was evaluated for rhHex-A, rhHex-B, and rhHex-S after $1 \mathrm{~h}$ incubation at $37^{\circ} \mathrm{C}$ and different $\mathrm{pH}$ values. Results are shown as relative enzyme activity (\%) based on the highest enzyme activity value obtained for each enzyme. 

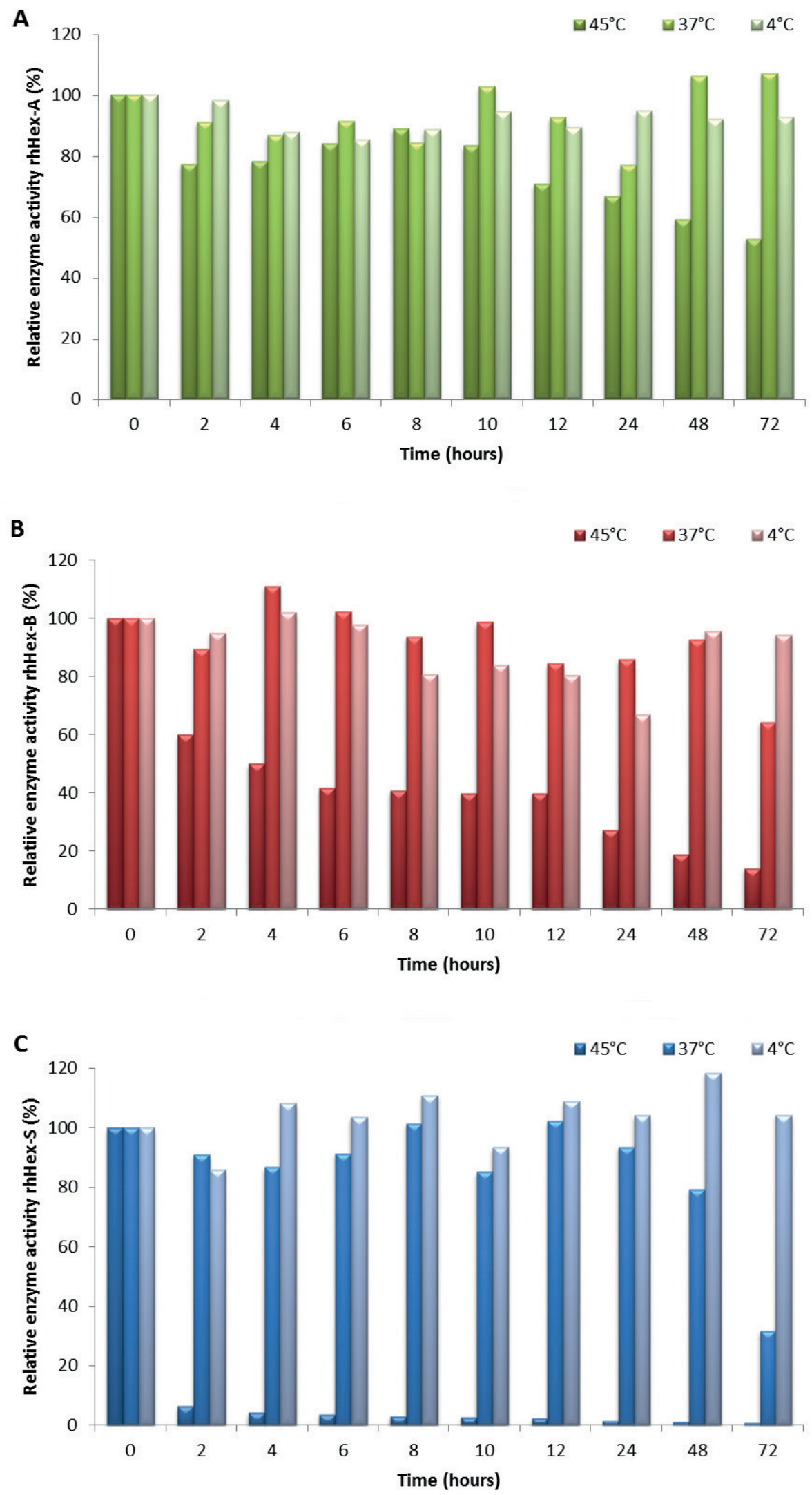

Figure 5. Effect of temperature on recombinant hexosaminidase enzyme activity. Enzyme activity was evaluated for rhHex-A (A), rhHex-B (B), and rhHex-S (C) after $72 \mathrm{~h}$ incubation at 4, 37, and $45{ }^{\circ} \mathrm{C}$. Results are presented as relative enzyme activity (\%) based on enzyme activity obtained at $0 \mathrm{~h}$. 
a final activity of $35 \%$ its initial activity levels after $72 \mathrm{~h}$ of incubation (Figure $5 \mathrm{~A}$ ). rhHex-B showed a remarkable stability at 4 and $37^{\circ} \mathrm{C}$, although after $72 \mathrm{~h}$ at $37^{\circ} \mathrm{C}$ enzyme activity was reduced by $40 \%$ compared with initial levels. At $45{ }^{\circ} \mathrm{C}$ rhHex-B there was a stark reduction in enzyme activity after $2 \mathrm{~h}$ of incubation (40\% of initial levels), reaching a $90 \%$ decrease after $72 \mathrm{~h}$ (Figure 5B). Last, rhHex-S also showed high stability at 4 and $37^{\circ} \mathrm{C}$, with an $80 \%$ reduction after $72 \mathrm{~h}$ of incubation at $37^{\circ} \mathrm{C}$. At $45{ }^{\circ} \mathrm{C}$ rhHex-S showed the highest thermolabile behavior of the studied enzymes, with enzyme activity reduction above $90 \%$ after the first $2 \mathrm{~h}$ of incubation (Figure $5 \mathrm{C}$ ).

$\beta$-subunit has been reported as the most stable intracellular subunit [57]. Therefore, a $52{ }^{\circ} \mathrm{C}$ inactivation is commonly used during Hex-A enzyme activity assay in plasma samples [40]. Taken together, the results obtained in this study suggest $\beta$-subunit rhHex-B produced in P. pastoris GS115 has a profile slightly different to previous thermostability reports. Geiger et. al. showed that at 40 and $50{ }^{\circ} \mathrm{C}, \mathrm{Hex}-\mathrm{B}$ was the most stable among hexosaminidases, losing its activity at $60^{\circ} \mathrm{C}$, as well as Hex-A and Hex-S [7]. In contrast, Krejsová et. al. described a recombinant Hex-B produced in yeast with stability at $65^{\circ} \mathrm{C}[23]$.

Regarding rhHex-S, temperature stability profile is in agreement with previous reports showing low $\alpha$-subunit stability [57]. Last, rhHex-A obtained in this study showed an important stability at $45{ }^{\circ} \mathrm{C}$ during 8 hours of incubation, which contrasts with liver extracted isozyme that lost a $10 \%$ activity just after 10 min incubation at $40{ }^{\circ} \mathrm{C}[7]$.

Lastly, stability of recombinant $\beta$-hexosaminidases was evaluated in human serum spiked with recombinant enzymes. Activity of Hex-A and Hex-B in non-spiked human serum was between 700 and 3,000 $\mathrm{U} \cdot \mathrm{mg}^{-1}$ and 1,000 and 1,800 $\mathrm{U} \cdot \mathrm{mg}^{-1}$, respectively. Hex-S was not determined by this method since it is considered a less important isozyme in human blood samples. Addition of recombinant $\beta$-hexosaminidases to human serum increased the activity between 5- and 83-fold in comparison with levels

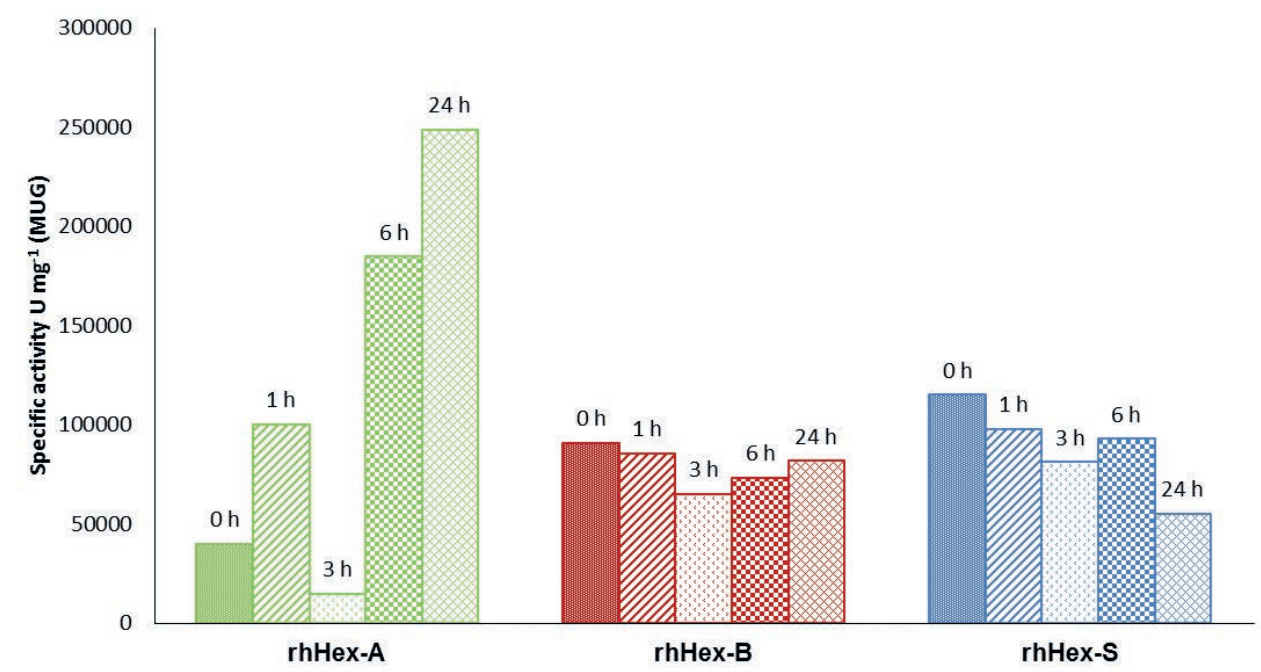

Figure 6. Effect of $\mathrm{pH}$ on recombinant hexosaminidase enzyme activity. Enzyme activity was evaluated for rhHex-A, rhHex-B, and rhHex-S after $1 \mathrm{~h}$ incubation at $37^{\circ} \mathrm{C}$ and different $\mathrm{pH}$ values. Results are shown as relative enzyme activity (\%) based on the highest enzyme activity value obtained for each enzyme. 
observed in human control serum. It was observed that rhHex-B and rhHex-S did not show an important reduction in enzyme activity within $24 \mathrm{~h}$ of incubation, while rhHex-A presented an unexpected activity profile, since an increase in enzyme activity was observed throughout time (Figure 6). Explanation regarding this unexpected increase is still under evaluation.

Although recombinant human $\beta$-hexosaminidases have been produced separately in different yeasts $[21-23,48]$, this study reports the production and characterization of the three recombinant human $\beta$-hexosaminidases using the same yeast strain (i.e. Pichia pastoris GS115), which allows for better enzyme characteristic comparison. In summary, these results demonstrated recombinant hexosaminidases obtained from P. pastoris GS115 have similar stability characteristics compared to human tissue extracted enzymes (native enzymes). This is an important finding requiring further evaluation for future therapeutic use.

\section{Conclusions}

In this study, we described human recombinant Hex-A, Hex-B, and Hex-S production and characterization. These enzymes were produced within the same host by using the methylotrophic yeast $P$. pastoris GS115. Purified enzymes showed enzyme activities of $1.4 \times 10^{6}$ (rhHex-A); $1.3 \times 10^{6}$ (rhHex-B); and $1.4 \times 10^{6}$ (rhHex-S) $\mathrm{U} . \mathrm{mg}^{-1}$. These recombinant proteins were stable under different $\mathrm{pH}$ and temperature conditions, as well as in human serum. Nevertheless, rhHex-B showed a slightly lower thermostability, while rhHex-A was more stable than that reported for human native hexosaminidases. This is not surprising since it is well known that proteins could be slightly different depending on organism and/or tissue in which they are produced. Thus, these results offer valuable findings regarding $P$. pastoris importance as an expression host for recombinant enzymes production with potential application for Enzyme Replacement Therapy. However, further studies should focus on in-vitro and in-vivo recombinant enzyme GM2 ganglioside tissue metabolism evaluation, as well as the effect on disease phenotype.

\section{Acknowledgment}

$\mathrm{AE}$ and AR received a doctoral scholarship from the Administrative Department of Science, Technology and Innovation COLCIENCIAS, Colombia, and the Pontificia Universidad Javeriana, respectively. AM and LB received a Young Researcher scholarship from COLCIENCIAS. DD received a Young Researcher scholarship from Pontificia Universidad Javeriana. CJAD was supported by Pontificia Universidad Javeriana (ID proposal 3964 and 5537) and COLCIENCIAS (Grant No. 120356933205 and 120356933427). LAB was supported by Pontificia Universidad Javeriana (Grant ID 3637) and COLCIENCIAS (Grant No. 120352128575). We thank Dr. Lawrence Dangott, Protein Chemistry Laboratory, and Dr. Frank Raushel, Department of Chemistry, Texas A\&M University for their assistance with assay development for protein characterization. We also thank Eng. Freddy Ruiz, Department of Electronic Engineering, Pontificia Universidad Javeriana for his assistance during methanol sensor implementation. Financing agencies had no role in study design, data collection and analysis, decision to publish, or preparation of the manuscript.

\section{Conflicts of Interest}

The authors declare no competing financial interests. 


\section{References}

1. Tropak M, Mahuran DJ. Tay-Sachs Disease, in Encyclopedia of Life Sciences (ELS), J.W. Sons, Editor. 2010.

doi: 10.1002/9780470015902.a0006019.pub2

2. Slámová K, Bojarová P, Petrásková L, Kren V. $\beta$-N-acetylhexosaminidase: what's in a name...?, Biotechnology Advances, 28: 682-93, 2010.

doi: 10.1016/j.biotechadv.2010.04.004

3. Tallman JF, Johnson WG, Brady R. The Metabolism of Tay-Sachs Ganglioside: Catabolic Studies with Lysosomal Enzymes from Normal and Tay-Sachs Brain Tissue, Journal of Clinical Investigations, 51: 2339 - 2345, 1972.

doi: 10.1172/JCI107045

4. Kolter T, Sandhoff K. Sphingolipid metabolism diseases, Biochimica et Biophysica Acta, 1758: 2057-2079, 2006.

doi: 10.1016/j.bbamem.2006.05.027

5. Matsuoka K, Tamura T, Tsuji D, Dohzono Y, Kitakaze K, Ohno K, Saito S, Sakuraba $\mathrm{H}$, Itoh K. Therapeutic Potential of Intracerebroventricular Replacement of Modified Human B-Hexosaminidase B for GM2 gangliosidoses, Molecular Therapy, 19 1017-1024, 2011.

doi: $10.1038 / \mathrm{mt} .2011 .27$

6. Tsuji D, Akeboshi H, Matsuoka K, Yasuoka H, Miyasaki E, Kasahara Y, Kawashima I, Chiba Y, Jigami Y, Taki T, Sakuraba H, Itoh K. Highly Phosphomannosylated Enzyme Replacement Therapy for GM2 Gangliosidosis, Annals of Neurology, 69: 691-701, 2011.

doi: 10.1002/ana.22262

7. Geiger B, Arnon R, Sandhoff K. Immunochemical and Biochemical Investigation of Hexosaminidase S, The American Journal of Human Genetics, 29: 508-522, 1977.

8. Dewji NN. Purification and characterization of beta-N-acetylhexosaminidase I2 from human liver, Biochemical Journal, 234: 157 - 162, 1986.

doi: 10.1042/bj2340157

9. Conzelmann E, Sandhoff K, Nehrkorn H, Geiger B, Arnon R. Purification, Biochemical and Immunological Characterisation of Hexosaminidase A from Variant AB of Infantile GM2 Gangliosidosis, European Journal of Biochemistry, 84: $27-33,1978$.

doi: 10.1111/j.1432-1033.1978.tb12137.x

10. Potier M, Teitelbaum J, Melancon SB, Dallaire L. Purification and some properties of liver and brain $\beta$-N-Acetyl-hexosaminidase S, Biocbimica et Biophysica Acta, 566: 80-87, 1979.

doi: 10.1016/0005-2744(79)90251-1

11. Ikonne JU, Rattazzi MC, Desnick RJ. Characterization of Hex S, the Major Residual B-Hexosaminidase Activity in Type 0 GM2 Gangliosidosis (Sandhoff-Jatzkewitz Disease), The American Journal of Human Genetics, 27: 639 - 650, 1975.

12. Srivastava SK, Wiktorowicz JE, Awasthi YC. Interrelationship of hexosaminidases $\mathrm{A}$ and B: Confirmation of the common and the unique subunit theory, Proceedings of the National Academy of Sciences USA, 73: 2833-2837, 1976.

doi: $10.1073 /$ pnas.73.8.2833 
13. Mahuran DJ, Neote K, Klavins MH, Leung A, Gravel RA. Proteolytic Processing of Pro-a and Pro-B Precursors from Human B-Hexosaminidase. Generation of the mature a and BaBb subunits, The Journal of Biological Chemistry, 263: 4612-4618, 1988.

14. Mark BL, Mahuran DJ, Cherney MM, Zhao D, Knapp S, James MNG. Crystal Structure of Human $\beta$-Hexosaminidase B: Understanding the Molecular Basis of Sandhoff and Tay-Sachs Disease, Journal of Molecular Biology, 327: 1093-1109, 2003. doi: 10.1016/S0022-2836(03)00216-X

15. Lemieux MJ, Mark BL, Cherney MM, Withers SG, Mahuran DJ, James MNG. Crystallographic Structure of Human b-Hexosaminidase A: Interpretation of TaySachs Mutations and Loss of GM2 Ganglioside Hydrolysis, Journal of Molecular Biology, 359: 913-929, 2006.

doi: 10.1016/j.jmb.2006.04.004

16. Ohsawa M, Kotani M, Tajima Y, Tsuji D, Ishibashi Y, Kuroki A, Itoh K, Watabe K, Sango K, Yamanaka S, Sakuraba H. Establishment of immortalized Schwann cells from Sandhoff mice and corrective effect of recombinant human betahexosaminidase A on the accumulated GM2 ganglioside, Journal of Human Genetics, 50: 460-7, 2005.

doi: 10.1007/s10038-005-0278-0

17. Pennybacker M, Liessem B, Moczall H, Tifft CJ, Sandhoff K, Proia RL. Identification of Domains in Human B-Hexosaminidase That Determine Substrate Specificity, The Journal of Biological Chemistry, 271: 17377-17382, 1996.

doi: 10.1074/jbc.271.29.17377

18. Fernandes MJG, Yew S, Leclerc D, Henrissat B, Vorgiasi CE, Gravel RA, Hechtman P, Kaplan F. Identification of Candidate Active Site Residues in Lysosomal b-Hexosaminidase A, The Journal of Biological Chemistry, 272: 814-820, 1997.

doi: $10.1074 /$ jbc.272.2.814

19. Hepbildikler ST, Sandhoff R, Kolzer M, Proia RL, Sandhoff K. Physiological Substrates for Human Lysosomal B-Hexosaminidase S, The Journal of Biological Chemistry, 277: 2562-2572, 2002.

doi: 10.1074/jbc.M105457200

20. Boose JA, Tifft CJ, Proia RL, Myerowitz R. Synthesis of a Human Lysosomal Enzyme B-Hexosaminidase B, Using the Baculovirus Expression System, Protein Expression and Purification, 1: 11-120, 1990.

doi: 10.1016/1046-5928(90)90003-H

21. Akeboshi H, Kasahara Y, Tsuji D, Itoh K, Sakuraba H, Chiba Y, Jigami Y. Production of human $\beta$-hexosaminidase A with highly phosphorylated N-glycans by the overexpression of the Ogataea minuta MNN4 gene, Glycobiology, 19: 1002-1009, 2009.

doi: 10.1093/glycob/cwp080

22. Akeboshi H, Chiba Y, Kasahara Y, Takashiba M, Takaoka Y, Ohsawa M, Tajima Y, Kawashima I, Tsuji D, Itoh K, Sakuraba H, Jigami Y. Production of Recombinant B-Hexosaminidase A, a Potential Enzyme for Replacement Therapy for Tay-Sachs and Sandhoff Diseases, in the Methylotrophic Yeast Ogataea minuta, Journal of Applied and Environmental Microbiology, 73: 4805-4812, 2007.

doi: 10.1128/AEM.00463-07

23. Krejzová J, Kulik N, Slámová K, Křen V. Expression of human $\beta-\mathrm{N}-$ acetylhexosaminidase $\mathrm{B}$ in yeast eases the search for selective inhibitors, Ensyme and Microbial Technology, 89: 1-6, 2016.

doi: 10.1016/j.enzmictec.2016.03.003 
24. Mahuran DJ. Characterization of Human Placental \&Hexosaminidase I2. Proteolytic Processing Intermediates of Hexosaminidase A, The Journal of Biological Chemistry, 265: 6794-6799, 1990.

25. Mahuran DJ, Tsui F, Gravel RA, Lowden JA. Evidence for two dissimilar polypeptide chains in the B2 subunit of hexosaminidase, Proceedings of the National Academy of Sciences USA, 79: 1602-1605, 1982.

doi: $10.1073 /$ pnas.79.5.1602

26. Srivastava SK, Awasthi YC, Yoshida A, Beutler E. Studies on Human $\beta-D-N-$ Acetylhexosaminidases. I. Purification and properties, Journal Biological Chemistry, 249: 2043-2048, 1974.

27. Espejo-Mojica Á, Alméciga-Díaz CJ, Rodríguez A, Mosquera Á, Díaz D, Beltrán L, Díaz S, Pimentel N, Moreno J, Sánchez J, Sánchez OF, Córdoba H, Poutou-Piñales RA, Barrera LA, Human recombinant lysosomal enzymes produced in microorganisms, Molecular Genetics and Metabolism, 2015.

doi: 10.1016/j.ymgme.2015.06.001

28. Córdoba-Ruiz HA, Poutou-Piñales RA, Echeverri-Peña OY, Algecira-Enciso NA, Landázuri P, Sáenz H, Barrera-Avellaneda LA. Laboratory scale production of the human recombinant iduronate 2-sulfate sulfatase-Like from Pichia pastoris, African Journal of Biotechnology, 8: 1786-1792, 2009.

doi: $10.5897 /$ AJB2009.000-9255

29. Poutou-Piñales RA, Vanegas A, Landázuri P, Sáenz H, Lareo L, Echeverri O, Barrera LA. Human sulfatase transiently and functionally active expressed in E. coli K12, Electronic Journal of Biotechnology, 13, 2010.

doi: 10.2225/vol13-issue3-fulltext-8

30. Rodriguez A, Espejo AJ, Hernandez A, Velasquez OL, Lizaraso LM, Cordoba HA, Sanchez OF, Almeciga-Diaz CJ, Barrera LA. Enzyme replacement therapy for Morquio A: an active recombinant N-acetylgalactosamine-6-sulfate sulfatase produced in Escherichia coli BL21, Journal of Industrial Microbiology and Biotechnology, 37: 1193-201, 2010.

doi: 10.1007/s10295-010-0766-x

31. Landázuri P, Poutou-Piñales RA, Acero-Godoy J, Córdoba-Ruiz H, Echeverri-Peña OY, Sáenz H, Delgado J, Barrera-Avellaneda LA. Cloning and shake flask expression of hrIDS-Like in Pichia pastoris, African Journals Biotechnology, 8: 2871-2877, 2009.

32. Ausubel FM, Brent R, Kingston RE, Moore DD. Short Protocols in Molecular Biology: A compendium of methods from Current Protocols in Molecular Biology. 4th ed, ed. J.W. Sons. 1999.

33. Ayra-Pardo C, Martínez GC, De la Riva GA. Single-Step Screening Procedure for Pichia pastoris Clones by PCR, Biotecnología Aplicada, 15: 173-175, 1998.

34. Stratton J, Chiruvolu V, Meagher M. High Cell-Density Fermentation, in Pichia Protocols, D.R. Higgins and J.M. Cregg, Editors. Humana Press: Totowa, New Jersey. 107-120. 1998.

35. Sinha J, Plantz BA, Inan M, Meagher M. Causes of proteolytic degradation of secreted recombinant proteins produced in methylotrophic yeast Pichia pastoris: case study with recombinant ovine interferon-tau, Biotechnology and Bioengeniering, 89: 102-12, 2005.

36. Laemmli UK. Cleavage of structural proteins during the assembly of the head of bacteriophage T4, Nature, 227: 680-685, 1970.

doi: $10.1038 / 227680 \mathrm{a} 0$

37. Mozdzanowsky J, Hembach P, Speicher DW. High yield electroblotting onto polyvinylidinedifluoride membranes from polyacrylamide gels, Electrophoresis, 13: 59-64, 1992. 
38. Edman P. Method for Determination of the Amino Acid Sequence in Peptides, Acta Chemica Scandinava, 4: 283-293, 1950.

doi: 10.3891/acta.chem.scand.04-0283

39. Shevchenko A, Tomas H, Havlis J, Olsen JV, Mann M. In-gel digestion for mass spectrometric characterization of proteins and proteomes, Nature Protocols, 1: 2856 2860, 2006.

40. Shapira E, Blitzer MG, Miller JB, Africk DK. Biochemical Genetics. A Laboratory Manual, ed. N.Y.O.U. Press. New York Okford. 1989.

41. Wendeler M, Sandhoff K. Hexosaminidase assays, Glycoconjugate journal, 26: 945952, 2009

42. Li P, Anumanthan A, Gao X-G, Ilangovan K, Suzara VV, Düzgüneş N, Renugopalakrishnan V. Expression of Recombinant Proteins in Pichia Pastoris, Applied Biochemistry and Biotechnology, 142: 105-124, 2007.

doi: 10.1007/s12010-007-0003-x

43. Cereghino GP, Cereghino J, Ilgen C, Cregg JM. Production of recombinant proteins in fermenter cultures of the yeast Pichia pastoris, Current Opinion in Biotechnology, 13: 329-332, 2002.

doi: 10.1016/S0958-1669(02)00330-0

44. Potvin G, Ahmad A, Zhang Z. Bioprocess engineering aspects of heterologous protein production in Pichia pastoris: A review, Biochemical Engineering Journal, 64: 91-105, 2012.

doi: $10.1016 /$ j.bej.2010.07.017

45. Trentmann O, Khatri NK, Hoffmann F. Reduced Oxygen Supply Increases Process Stability and Product Yield with Recombinant Pichia pastoris, Biotechnology Progress, 20: 1766-1775, 2004.

doi: $10.1021 / \mathrm{bp} 049711 \mathrm{~h}$

46. Charoenrat T, Ketudat-Cairns M, Stendahl-Andersen H, Jahic M, Enfors S-O. Oxygen-limited fed-batch process: an alternative control for Pichia pastoris recombinant protein processes, Bioprocess and Biosystem Engineering, 27: 399-406, 2005. doi: 10.1007/s00449-005-0005-4

47. Rodríguez-López A, Díaz D, Beltrán L, Sánchez J, Moreno J, Díaz S, Pimentel N, Mosquera A, Soto C, Pardo A, Velásquez O, Hernández A, Leonardi F, Espejo A, Córdoba H, Sánchez O, Alméciga-Diaz C, Barrera L. Production of active recombinant Human sulfatases Iduronate-2-sulfate and N-acetylgalactosamine-6sulfate in microorganisms, Journal of Inborn Errors of Metabolism and Screening, 2: 76, 2014. doi: 10.1016/j.ymgme.2013.12.023

48. Prezant TR. Expression of human lysosomal beta-hexosaminidase in yeast vacuoles, Biochemical and Biophysical Research Communications, 170: 383-90, 1990.

49. Tallman JF, Brady RO, Quirk JM, Villalba M, Gal AE. Isolation and Relationship of Human Hexosaminidases, The Journal of Biological Chemistry, 249: 3489-399, 1974.

50. McCurdy VJ, Rockwell HE, Arthur JR, Bradbury AM, Johnson AK, Randle AN, Brunson BL, Hwang M, Gray-Edwards HL, Morrison NE, Johnson JA, Baker HJ, Cox NR, Seyfried TN, Sena-Esteves M, Martin DR. Widespread correction of central nervous system disease after intracranial gene therapy in a feline model of Sandhoff disease, Gene Therapy, 22: 181-189, 2015.

51. Bradbury AM, Cochran JN, McCurdy VJ, Johnson AK, Brunson BL, Gray-Edwards H, Leroy SG, Hwang M, Randle AN, Jackson LS, Morrison NE, Baek RC, Seyfried TN, Cheng SH, Cox NR, Baker HJ, Cachón-González MB, Cox TM, Sena-Esteves M, Martin DR. Therapeutic Response in Feline Sandhoff Disease Despite Immunity to Intracranial Gene Therapy, Molecular Therapy, 21: 1306-1315, 2013. 
52. Okochi T, Seike H, Higashino K, Hada T, Watanabe S, Yamamura Y, Ito F, Matsuda M, Osafune M, Kotake T, Sonoda T. Alteration of hexosaminidase isozymes in human renal carcinoma, Cancer Research, 39: 1829-34, 1979.

53. Sola RJ, Griebenow K. Glycosylation of therapeutic proteins: an effective strategy to optimize efficacy, BioDrugs, 24: 9-21, 2010.

doi: 10.2165/11530550-000000000-00000

54. Du H, Levine M, Ganesa C, Witte DP, Cole ES, Grabowski GA. The role of mannosylated enzyme and the mannose receptor in enzyme replacement therapy, The American Journal of Human Genetics, 77: 1061-74, 2005.

doi: $10.1086 / 498652$

55. Laukens B, De Visscher C, Callewaert N. Engineering yeast for producing human glycoproteins: where are we now?, Future Microbiology, 10: 21-34, 2015.

doi: $10.2217 /$ fmb.14.104

56. Srivastava SK, Awasthi YC. Metabolic disorders in sphingolipidoses, in Biochemistry of brain, S. Kumar, Editor.: Pergamosn 2- 47, 1980.

57. Zwiers K, Zalewska A, Zoch-Zwiers W. Isoenzymes of N-acetyl-B-hexosaminidase. Review, Acta Biochimica Polonica, 46: 739-751, 1999. 
Caracterización de beta-hexosaminidasas lisosomales humanas recombinantes producidas en la levadura metilotrófica Pichia pastoris

Resumen. Las $\beta$-hexosaminidasas (Hex) son enzimas diméricas involucradas en la degradación lisosomal de glicolípidos y glicanos. Estas enzimas están formadas por las subunidades $\alpha-y / o$ $\beta$-codificadas por los genes HEXA and HEXB respectivamente. Las mutaciones de estos genes conducen a las enfermedades de Tay Sachs o Sandhoff, que son desórdenes neurodegenerativos causados por la acumulación de glicolípidos no degradados. Aunque las Hex derivadas de tejido han sido ampliamente caracterizadas, la información disponible sobre las $\beta$-hexosaminidasas recombinantes es limitada. En este estudio se produjeron Hex recombinantes lisosomales (rhHex-A, rhHex-B y rhHex-S) en la levadura metilotrófica Pichia pastoris GS115. Las actividades específicas más altas de las enzimas fueron 13.124, 12.779, $14.606 \mathrm{U} . \mathrm{mg}^{-1}$ para rhHex-A, rhHex-B y rhHex-S, respectivamente. Estos resultados fueron 25 a 50 veces más altos que los obtenidos de leucocitos humanos normales. Las proteínas se purificaron y se caracterizaron a diferentes condiciones de $\mathrm{pH}$ y temperatura. Todas las proteínas fueron estables a $\mathrm{pH}$ ácido y a $4^{\circ} \mathrm{C}$ y $37^{\circ} \mathrm{C}$. A $45^{\circ} \mathrm{C}$ la rhHex-S se inactivó completamente, mientras que rhHex-A y rhHex-B mostraron alta estabilidad. Este estudio demuestra el potencial de $P$. pastoris GS115 para la producción de enzimas lisosomales poliméricas y presenta la caracterización de distintas $\beta$-hexosaminidasas recombinantes producidas en un único hospedero.

Palabras clave: $\beta$-N-acetylhexosaminidasas; caracterización; Pichia pastoris; hexosaminidasas recombinantes; enfermedad de Sandhoff; enfermedad de Tay Sachs.

Caracterizaçáo de beta-hexosaminidases lisossomais humanas recombinantes produzidas na levedura metilotrófica Pichia pastoris

Resumen. As $\beta$-hexosaminidases (Hex) são enzimas diméricas envolvidas na degradação lisossomal de glicolipídeos e glicanos. Essas enzimas são formadas por subunidades $\alpha$ - e/ou $\beta$-codificadas pelos genes HEXA e HEXB, respectivamente. As mutações nesses genes causam a doença de Sandhoff ou Tay Sachs, que são desordens neurodegenerativas causadas pela acumulação de glicolipídeos não degradados. Embora Hex derivadas de tecido hajam sido caracterizadas extensivamente, as informações disponíveis sobre as $\beta$-hexosaminidases recombinantes são limitadas. Esse estudo produziu Hex recombinantes lisossomais (rhHex-A, rhHex-B e rhHex-S) na levedura metilotrófica Pichia pastoris GS115. As atividades específicas mais altas das enzimas foram 13.124, 12.779, 14.606 $\mathrm{U} . \mathrm{mg}^{-1}$ para rhHex-A, rhHex-B y rhHex-S, respectivamente. Esses resultados foram 25 a 50 vezes mais altos do que os obtidos a partir de leucócitos humanos normais. As proteínas foram purificadas e caracterizadas em diferentes condições de $\mathrm{pH}$ e temperatura. Todas as proteínas foram estáveis a $\mathrm{pH}$ ácido e a $4^{\circ} \mathrm{C}$ e $37^{\circ} \mathrm{C}$. A $45^{\circ} \mathrm{C}$ a rhHex-S foi completamente inativada, enquanto rhHex rhHex-A e B se mostraram altamente estáveis. Esse estudo demonstra o potencial de $P$. pastoris GS115 para a produção de enzimas lisossomais poliméricas e apresenta a caracterização de diferentes $\beta$-hexosaminidases recombinantes produzidas em único hospedeiro.

Palabras clave: $\beta$-N-acetilhexosaminidases, caracterização, Pichia pastoris, hexosaminidases recombinantes, Doença de Sandhoff, Doenca de Tay Sachs. 
Angela J. Espejo-Mojica

Industrial Microbiologist, and Doctor in Biological Sciences.

Angela Mosquera

Industrial Microbiologist, Medical Laboratory Scientist and Ph.D student.

Alexander Rodríguez-López

Bachelor in Chemistry, and Ph.D. candidate.

Dennis Díaz

Industrial Microbiologist, and M.Sc. in Biological Science.

Laura Beltrán

Industrial Microbiologist.

Liliana Hernandez

Industrial Microbiologist.

Carlos J. Alméciga-Díaz

Bachelor of Pharmacy, and Doctor in Biological Science.

Luis A. Barrera

Bachelor in Chemist and Biologist, M.Sc. in Biochemistry, and Doctor in Biochemistry. 